\title{
Why we shouldn't shy away from discussions around decolonising curricula
}

\author{
Danielle Tran \\ University of Greenwich
}

Within the last decade, there has been a steady growth of literature discussing the benefits of internationalising curricula, strategies for making curricula more international and the possible impact of such an approach on students' experience during their time at university and in the world of work beyond. In an 'Internationalising the curriculum toolkit' by Liverpool John Moores University (no date), "internationalisation of the curriculum [is seen] as one of the key steps in encouraging global perspectives, knowledge and understandings that enhances employability in a global economy, promotes inclusivity, equality and a diverse and enriched learning experience for all". Such a definition of internationalising the curriculum has clear connections to the argument for decolonising the curriculum something which has been gaining momentum within the critical sphere. Yet the definition for decolonisation of curricula continues to be debated. Whilst both internationalising and decolonising of curricula call for a review of course content and delivery in light of the diverse body of students in our classrooms, there is a difference between an internationalisation and a decolonising of curricula - a difference that should not be overlooked.

For some, the term 'internationalisation' may be more comfortable to use, as it emphasises the notion of inclusivity and globality. Hesitancy about discussing a 'decolonising of curricula' may derive from a sense that this phrase is possibly loaded, engaging directly as it does with a history that cannot be adequately discussed without addressing how issues of race, power, and trauma have come to be at its core. In an opinion piece for The Guardian, Gopal (2017) notes, "A decolonised curriculum would bring questions of class, caste, race, gender, ability and sexuality into dialogue with each other, instead of pretending that there is some kind of generic identity we all share [...] Ultimately, to decolonise is to ask difficult questions of ourselves".

But these interconnected issues must not be ignored. Students are making it clear that they want higher education institutions (HEls) to address the matter - as illustrated by the campaigns for the decolonising of education led by students at the University of Sussex (2016 and continuing) and University College London (2018). Relevant conversations in HEIs, both nationally and internationally, are increasingly generating a more attentive response to questions about what is being taught, how it is being taught and who is delivering the teaching, with consequent healthy discussions - which may well spread beyond an institution - about class, gender and race.

I took part in the 'Widening Success in Higher Education' 2017 project (funded by the British Council and managed by Cape Peninsula University of Technology and the University of East London), which explored strategies for increasing participation within higher education, ensuring student success and enhancing employability. My experience of this project was very positive, on account of the developmental conversations that can (and did!) occur when participants push past any discomfort they may feel about discussing decolonising curricula. 
The workshops encouraged me to reflect more deeply upon my understanding and use of the terms 'internationalising' and 'decolonising' of curriculum; I gained a better understanding of the differences between these two terms and a better sense of the value to be derived from discussing the latter. These exchanges were at times sensitive, difficult and challenging; however, it became clear that it is important to transcend personal feelings in such discussion in order to develop understanding, acknowledge all views and achieve constructive reflection on whether or not these issues are being addressed and acknowledged in our classrooms: If they are, how? If they are not, why not? New opportunities for dialogue may open up if we are aware of a number of things: how we are seen in the classroom; how we see our students; who is in our classroom - not just who our students are now, but how their views and understanding of the world have been formed; how different views can be acknowledged in classroom spaces.

Having taken the first important psychological step (viz. not to shy away from the potentially difficult conversations that can be opened up from a discussion of decolonising curricula), we must be open and embrace hard discussions. To be professional and committed teachers, we must not evade conversation which is challenging, but recognise its vital importance, listen to students' expression of their needs and concerns, acknowledge these and engage and respond thoughtfully. Decolonising curricula should be viewed as a critical point of discussion which encourages reflection and allows for positive developments towards the creation of a more inclusive, diverse curriculum and learning experience.

\section{Reference list}

Gopal, P. (2017) 'Yes, we must decolonise: our teaching has to go beyond elite white men.' The Guardian (27 October 2017). Available at:

https://www.theguardian.com/commentisfree/2017/oct/27/decolonise-elite-white-mendecolonising-cambridge-university-english-curriculum-literature (Accessed: 31 October 2018).

Liverpool John Moores University (no date) Internationalising the Curriculum: A toolkit. Available at: https://www.heacademy.ac.uk/system/files/internationalisation toolkit.pdf (Accessed: 31 October 2018).

University of Sussex Students' Union (2018) Decolonise Education. (Student campaign) Available at: https://www.sussexstudent.com/campaigns/decolonize-education/ (Accesssed: 21 May 2018).

Students' Union UCL (2018) Decolonise UCL. (Student campaign) Available at: http://studentsunionucl.org/make-change/what-were-working-on-0/decolonise-ucl (Accessed: 21 May 2018). 